\section{REMOVAL OF OIL AND REDUCTION OF BOD FROM PALM OIL MILL EFFLUENT (POME) USING POLYURETHANE NANOFIBERS}

\author{
Zykamilia Kamina,b*, Norhayati Asganc, Rosalam Sarbatlyc, \\ Duduku Krishnaiahc
}

aEnergy Research Unit, Faculty of Engineering, Universiti Malaysia Sabah, Jalan UMS, 88400, Kota Kinabalu, Sabah, Malaysia bOil and Gas Engineering Programme, Faculty of Engineering, Universiti Malaysia Sabah, Jalan UMS, 88400, Kota Kinabalu, Sabah, Malaysia

Chemical Engineering Programme, Faculty of Engineering, Universiti Malaysia Sabah, Jalan UMS, 88400, Kota Kinabalu, Sabah, Malaysia
Article history

Received

21 May 2019

Received in revised form 30 September 2019

Accepted

2 October 2019

Published online

25 December 2019

*Corresponding author zykamilia@ums.edu.my

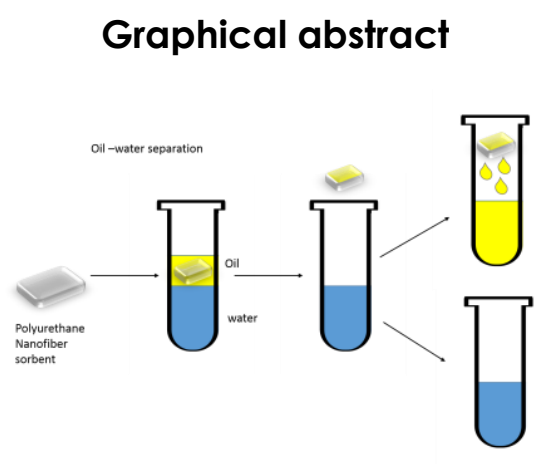

\begin{abstract}
The effluent of the palm oil mill is known as palm oil mill effluent (POME) constituting water, oil and solid. Upon discharge from the mill, POME goes into an anaerobic pond system which is not environmentally friendly. The threats, mainly come from the accumulated oil inside the pond. Therefore, this study attempt to find a solution for this problem by using polyurethane nanofiber to sorb the oil from the POME due to its oleophilic and hydrophobic properties. The nanofibers were characterized by scanning electron microscopy (SEM), oil sorption capacity, amount of extracted oil of POME and Biological Oxygen Demand (BOD) content after sorption. The result shows the nanofibers average diameter is $3.0 \times 10^{3} \mathrm{~nm}$, about $31.40 \mathrm{~g} / \mathrm{g}$ oil sorption capacity, $48 \%$ oil extracted from the POME and the BOD content was reduced to $10 \mathrm{mg} / \mathrm{l}$. This result shows that nanofiber sorbent is a viable method to not only protect the environment, but also has the potential for recovery the oil.

Keywords: Nanofiber, oil sorption capacity, oil extraction, BOD, POME
\end{abstract}

\begin{abstract}
Abstrak
Sisa buangan kilang minyak sawit dikenali sebagai efluen kilang minyak sawit (POME) terdiri daripada air, minyak dan pepejal. Setelah dilepaskan dari kilang, POME disalurkan ke sistem kolam anaerobik yang tidak mesra alam, yang mana sebahagian besarnya terdiri daripada minyak yang terkumpul. Oleh itu, kajian ini cuba mencari penyelesaian untuk masalah ini dengan menggunakan gentian nano poliuretana untuk menyerap minyak dari POME kerana sifat oleofilik dan hidrofobiknya. Gentian nano dicirikan oleh pegimejan mikroskopi elektron (SEM), kapasiti penyerapan minyak, jumlah minyak yang diekstrak dan permintaan oksigen biokimia (BOD) selepas penyerapan. Keputusan menunjukkan bahawa diameter purata ialah $3.0 \times 10^{3} \mathrm{~nm}$, lebih kurang $31.40 \mathrm{~g} / \mathrm{g}$ kapasiti penyerapan minyak, $48 \%$ minyak yang diekstrak dari POME dan kandungan BOD dikurangkan kepada $10 \mathrm{mg} / \mathrm{L}$. Keputusan menunjukkan bahawa gentian nano adalah satu cara yang baik untuk tidak hanya melindungi alam sekitar tetapi juga mempunyai potensi untuk pemulihan minyak.

Kata kunci: Gentian nano, kapasiti penyerapan minyak, pengekstrakan minyak, BOD, POME
\end{abstract}




\subsection{INTRODUCTION}

Palm oil mills generate palm oil mill effluent (POME) during palm oil processing. In Malaysia, POME is one of the main sources of the industry producing oily wastewater. At least 44 million tonnes of POME were generated in Malaysia in the year 2008 [1]. Raw POME is a colloidal suspension containing $95-96 \%$ water, $0.6-0.7 \%$ oil and $4-5 \%$ total solids including $2-$ $4 \%$ suspended solids [2]. It is basically an oil-in-water emulsion among other contaminants. The oil concentration in POME usually in the range of 4000 to $8000 \mathrm{mg} / \mathrm{l}$ [3].

Emulsified oil in wastewater can lead to severe problems in different treatment stages. Oil in wastewaters has to be removed in order to, prevent interfaces in water treatment units, reduce fouling in process equipment, avoid problems in biological treatment stages and comply with the water discharge standard requirement. Furthermore, oil and grease are hazardous pollutants of the aquatic organisms because they are highly toxic and can completely damage the ecology of the aquatic ecosystem [4].

According to the Malaysian Environmental Quality Act 1974 with a revision in 2005, the effluent discharge limit for crude palm oil mills is 50 and 100 $\mathrm{mg} / \mathrm{l}$ for oil and grease and BOD respectively [5].

The treatment of these wastes has been addressed by several techniques such as chemical destabilization by addition of organic and inorganic compounds [6, 7], absorption [8, 9], electrical methods [10], membrane processes [11] and dissolved air flotation [12-14].

The current most applied treatment methods of POME is by using anaerobic ponding system. However, it is not environmental friendly [13], requires a large area and long retention time. It also poses threat to the environment in which, if there is any occurrence of heavy rain, makes the POME to overflow into the river which sometimes is unaware by the authority. The threats, mainly come from the oil containing inside the POME most particularly those in grit pond where the POME has been accumulated over time, having high quantity of oil. Furthermore, pond system also often fails to produce treated water that complies with the standard of the Department of Environment of Malaysia [15].

Alternatively, polymeric nanofibers sorbent is proven to be ideal materials to separate oil from an aqueous solution due to its characteristic of high surface area-to-volume ratio, and complex pore structure [16-20]. In addition, the reusability [21] of the nanofiber sorbent also a key factor to consider.

To select the best sorbent, considerations that should be made include, buoyancy, saturation, oil retention and strength [22]. Furthermore, the sorbent must remain afloat when saturated with oil [23]. The oil will occupy the voids inside the sorbent and therefore become a semi solid [24]. Sorbent can be quickly saturated with oil and must be removed quickly to avoid any risk of oil leaching out from the sorbent, in which oil retention is also a key consideration for a good sorbent.

As for now, the method of producing nanofiber generally using electrospinning method [22], which has a low productivity, making the final product to become expensive and mostly used in high end application compared to as sorbent for waste oil. Some previous experiment shows that nanofibers has the capability to separate oil from oil-water mixture with high oil sorption capacity $[19,25]$. Previous researches use materials such as polystyrene $[19,26$, 27], polystyrene/polyurethane [28] and Polyvinyl chloride/polystyrene [17]. However, these nanofibers were produced using electrospinning technique [22]. Alternatively, melt blowing technique able to produce nano sized fibers in a mass scale in contrast to electrospinning [29-33].

Commonly, the sorption technique using nanofibers was used for oil spill clean-up [22], however, due to their oleophilic properties it can also be applied for POME. Therefore, this research focus on the oil sorption from POME using melt blown polyurethane nanofibers and subsequently attempting to find a solution for the POME of the palm oil industry.

\subsection{METHODOLOGY}

\subsection{Material}

A sample of polyurethane (PU) nanofibers used as sorbent material was obtained from the Tokyo Econet Limited Company in conjunction with a collaboration with the Universiti Malaysia Sabah. POME samples were obtained from Lumadan Palm Oil Mill Company, Beaufort at two locations, i.e. Raw POME at immediate outlet (POME-1) and grit pond POME (POME-2) as shown in Figure 1. The POME samples were kept in a refrigerator prior to use.

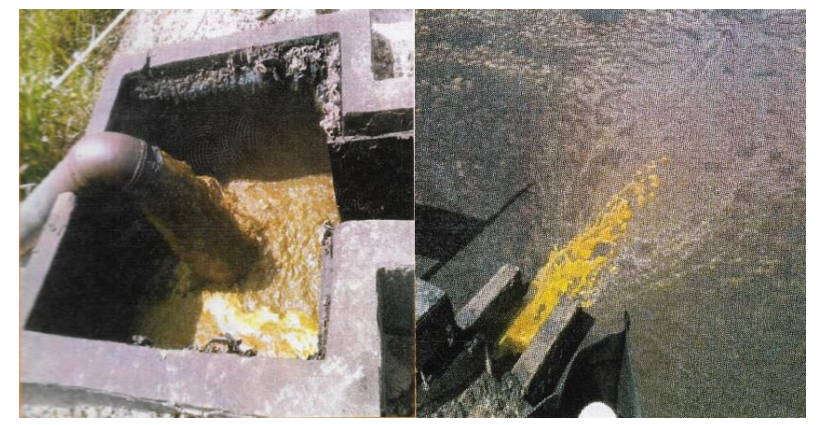

(a)

(b)

Figure 1 Sampling location of POME (a) immediate outlet (POME-1) and (b) grit pond (POME -2) 


\subsection{Determination of Fiber Diameter}

The PU nanofibers about the size of $2.25 \mathrm{~cm}^{2}$ was cut, coated and scanned using a Scanning Electron Microscopy (SEM). Several readings were taken at different spots using the same sample to determine the average diameter of the fibers.

\subsection{Determination of Oil Sorption Capacity of nanofiber at Varied Contact Time}

In order to analyse the oil sorption capacity of the PU nanofiber in POME, a $1.00 \mathrm{~g}$ of $\mathrm{PU}$ nanofiber was placed on top of a $100 \mathrm{~g}$ POME in a $250 \mathrm{~mL}$ beaker. After 2 minutes of contact time, the nanofiber was taken out and drained for 3 minutes. The difference between the POME initial weight and the weight after contact time was taken to determine the sorption capacity of the PU nanofiber. This procedure was conducted in 2, 4, 6, 8, and 10 minutes, for both POME-1 and POME-2.

\subsection{Determination of Oil Removal from the POME}

Since POME is constituted of various components, the oil and grease fraction from the POME was further investigated using extraction by using hexane with a purity of $99.9 \%$ as solvent. The ratio of solvent to POME was fixed at $1: 1$ and was carried at $28^{\circ} \mathrm{C} .200$ $\mathrm{ml}$ of hexane and $200 \mathrm{ml}$ POME were mixed in a flocculator for 10 minutes at $150 \mathrm{rpm}$. The contents were then transferred to a separating funnel and left to separate into two layers. The extract was filled into a conical flask and the solvent was distilled off using a rotary evaporator. The drying process was conducted in an oven at $102{ }^{\circ} \mathrm{C}$ for 15 minutes. The flask was then cooled in a desiccator for 3 minutes and weighted using four digits electronic balance. The measured weight was taken as oil and grease content value. These procedures were done for both POME before sorption and after the sorption by the nanofiber.

\subsection{Determination of BOD Using Dilution Technique}

Two BOD bottles were prepared with each contains $300 \mathrm{ml}$ of $\mathrm{POME}$, labelled $\mathrm{D}_{1}$ and $\mathrm{D}_{3} .1 \mathrm{~mL}$ of $\mathrm{MnSO}_{4}$ solution was pipetted into the sample inside the BOD bottle. Followed by $1 \mathrm{~mL}$ alkali-iodate azide reagent into $D_{1}$. When the precipitate has settled sufficiently, another $1 \mathrm{ml}$ of concentrated sulphuric acid was added into the BOD bottle $D_{1}$. The $D_{1}$ BOD bottle was closed with a stopper and mixed by inverting several times until dissolution. A $200 \mathrm{ml}$ of mixed sample was taken out from $D_{1}$ into the conical flask. Three drops of starch were added into the conical flask. The sample in conical flask was then titrated with $0.025 \mathrm{M}$ $\mathrm{Na}_{2} \mathrm{~S}_{2} \mathrm{O}_{3}$ solution until first disappearance of blue colour.

The procedure was repeated by replacing $D_{1}$ with $D_{2}$ after 3 days of incubation. The BOD values were calculated by using:

$$
B O D, m g / L=\left(D_{1}-D_{2}\right) / P
$$

Where,

$D_{1}=$ Dissolved Oxygen (DO) of diluted sample immediately after preparation, $\mathrm{mg} / \mathrm{L}$;

$\mathrm{D}_{2}=\mathrm{DO}$ of diluted sample after 3 days incubation at $20^{\circ} \mathrm{C}, \mathrm{mg} / \mathrm{L}$;

$\mathrm{P}=$ Decimal volumetric fraction of the sample used.

Subsequently, DO was calculated based on the DO ratio of $D_{1}$ and $D_{2}$ for each of the samples.

\subsection{RESULTS AND DISCUSSION}

\subsection{Fiber Diameters and Average Diameters}

As shown in the Figure 2 (a) - (c), it can be seen clearly the physical characteristic of this nanofiber. These Figures 1 (a) - (c), were captured by using SEM, in which the magnification of Figure 2 (a) and (b) were 100 and 3000 times respectively. Figure 1 (a) show that the nanofibers were made up from thousands of single fibers. Figure 2 (b) shows that, the average diameter of a single fiber was $3.0 \times 10^{3} \mathrm{~nm}$. Some isolated fibers show the diameter 2.331, 3.663 and $2.997 \times 10^{3} \mathrm{~nm}$ in Figure $2(\mathrm{~b})$ and 2.059 and 2.171 $\times 10^{3} \mathrm{~nm}$ in Figure 2 (c).

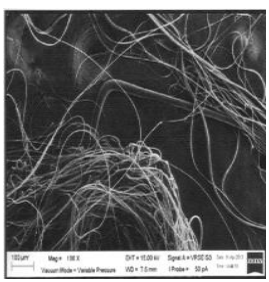

(a)

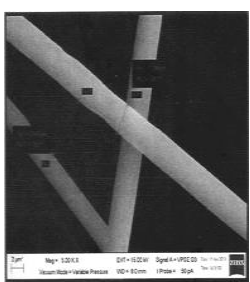

(b)

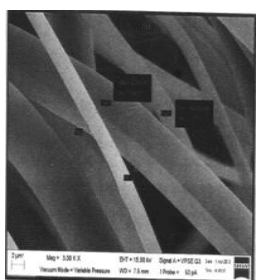

(c)
Figure 2 SEM micrographs of the samples (a) Magnification of 100 times and $(b, c)$ Magnification of 3000 times

This feature will lead to the formation of pores among the fibers, making this nanofibers to be highly porous. A high porosity is one of the main characteristic of an excellent sorbent for oil [22]. This is because the more porous the sorbent is, there is more area for more volume of oil to be attached on the inner and surface of the sorbent.

\subsection{Oil Sorption Capacity at Varied Time}

Initially, 5 minute interval of sorption time was used. Since the sorbents were observed to become saturated at 10 minutes and sorption process was decreasing, a shorter interval of 2 minutes was proposed. The results show an acceptable value. According to Table 1, the oil sorption capacity was increasing with time until it reaches the saturated time. Here the nanofiber was fully covered by the oil molecules and sorption process had to stop. The increasing of oil sorption capacity was due to the 
contact time for the oil molecules entering the voids among the nanofibers [22]. Subsequently, these oil molecules have a longer time for the sorption process to occur. Similar finding was observed in other previous study [17].

Besides that, the different values between POME1 and POME-2 shown in Table 1 and Figure 3 were due to the difference in the oil content in the samples. During collection, POME-1 and POME-2 were collected at $80^{\circ} \mathrm{C}$ and between 50 and $60^{\circ} \mathrm{C}$ respectively. Here POME-2, has cool down and accumulated more oil and having higher oil viscosity than POME-1.

Table 1 Sorption capacity of POME-1 and POME-2 at various contact times

\begin{tabular}{cll}
\hline Time, Min & \multicolumn{2}{c}{ Oil sorption capacity, g/g sorbent } \\
\hline & A (POME-1) & B (POME-2) \\
2 & 16.37 & 23.73 \\
4 & 21.30 & 27.10 \\
6 & 23.63 & 27.85 \\
8 & 26.31 & 28.51 \\
10 & 29.28 & 31.40 \\
\hline
\end{tabular}

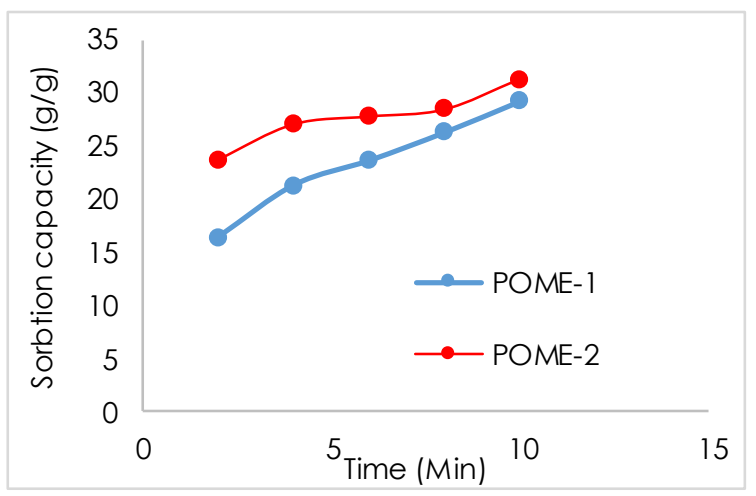

Figure 3 Oil sorption capacity of POME-1 and POME-2 at various contact times

Additionally, the raw POME-1 coming out directly from the plant falls into the grit pond, while the POME-2 in the grit pond has been gathered during a period of time, therefore accumulated more oil on the surface. This can be related to the viscosity of the POME, since a more viscous oil is easier to be trapped in the inter fiber voids of the nanofibers meanwhile a less viscous oil is easier to escape from the inter fiber voids $[18,19,22]$.

\subsection{Oil Removal from the POME}

In this experiment only POME-2 was used as it has shown a higher oil content compared to POME-1 in Section 3.2. According to Table 2 and Figure 4, at two minutes sorption, the percentage of removal was 33.80, whereas 48.31 at 10 minutes of sorption time. Here, there are more oil molecules sorbed into the nanofiber compared to the two minutes sorption due to the longer contact time leading to more oil being sorbed.

Table 2 Oil sorption capacity of POME-2 at various contact times

\begin{tabular}{cccc}
\hline Time, Min & $\begin{array}{c}\text { Oil content, } \mathbf{g} \\
\text { Before } \\
\text { sorption, } \mathbf{g}\end{array}$ & $\begin{array}{c}\text { After } \\
\text { sorption, } \mathbf{g}\end{array}$ & \% removal \\
\hline 2 & 21.58 & 14.28 & 33.80 \\
6 & 19.51 & 12.40 & 36.46 \\
10 & 37.78 & 19.53 & 48.31 \\
\hline
\end{tabular}

Figure 5 (a), shows that, the nanofiber was not fully saturated by the oil molecules when two minutes of contact time was applied indicated by the white section of the nanofibers. Meanwhile, the nanofiber was fully covered by the oil at 10 minutes contact time as shown in Figure 5 (b).

The oil removal for using nanofiber, was higher compared to other sorbents such as synthetic rubber powder that was also used to remove oil from POME. Ahmad et al., [34] reported that $30.00 \mathrm{~g}$ of synthetic rubber powder was used to remove $88 \%$ of oil from $100 \mathrm{ml}$ of POME for three hours.

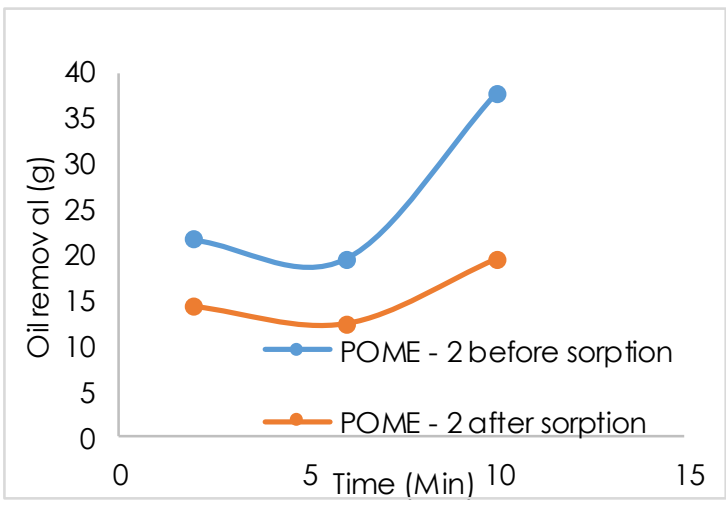

Figure 4 Oil extracted from POME-2 at various contact time before sorption and after sorption procedure

Wahi et al. [8] used $2.00 \mathrm{~g}$ of sago bark and esterified sago bark fiber waste to remove 39.6 and $53.46 \%$ of oil from $100 \mathrm{ml}$ of POME for 30 minutes.

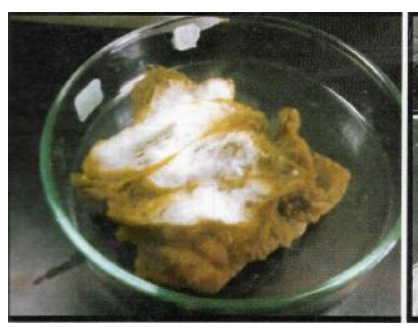

(a)

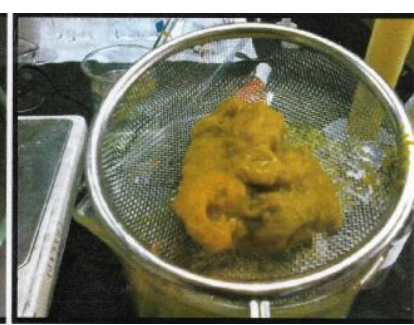

(b)
Figure 5 The physical observation of the nanofiber at (a) 2 minutes and (b) 10 minutes sorption 
Meanwhile from this research only $1 \mathrm{~g}$ of nanofiber was used to remove about $48 \%$ of POME within 10 minutes. This proves that the polyurethane nanofiber has better performance compared to the synthetic rubber powder and sago bark.

\subsection{BOD Measurement}

By referring to Table 3 and Figure 6, the highest $B O D$ value for the POME-2 was $60 \mathrm{mg} / \mathrm{l}$ before any sorption process. This is followed by sample 2,6 , and 10 minutes of sorption time with BOD values of 40,20 and $10 \mathrm{mg} / \mathrm{l}$ respectively.

Table 3 Value of biological oxygen demand (BOD) of the sample at various contact times

\begin{tabular}{cc}
\hline Sample (sorption time in minutes) & BOD $(\mathbf{m g} / \mathbf{l})$ \\
\hline 0 & 100 \\
2 & 40 \\
6 & 20 \\
10 & 10 \\
\hline
\end{tabular}

BOD is a measure of the oxygen used by microorganisms to decompose of organic matter. A high value of BOD indicates two things, there were a high level of microorganism in the sample and there was a high content of organic material in the water that is broken down by the microorganism. This an indication of organic pollution.

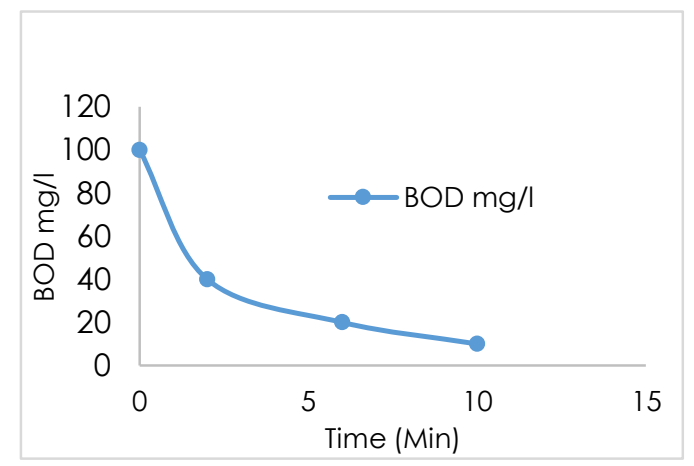

Figure 6 Value of biological oxygen demand (BOD of the sample at various contact times

From Figure 6, it can be seen that, the sample without sorption ( 0 minutes contact time) by sorbent has a high level of microorganism compared to others samples (2-10 minutes contact time) that has undergone a sorption process using the polyurethane nanofibers. The lowest level of BOD is shown by sample with 10 minutes of sorption time. By using the nanofibers some of the microorganism and organic materials were sorbed by the nanofiber therefore decreased the BOD values to well below the 100 $\mathrm{mg} / \mathrm{l}$.

Subsequently, the microorganism associated with POME includes Micrococcus sp., Bacillus sp.
Pseudomonas sp. and Staphylococcus aures [35]. These microorganisms have sizes of $0.5 \mu \mathrm{m}$ by $2.0 \mu \mathrm{m}$ for Micrococcus sp., $0.5-1.2 \mu \mathrm{m}$ by $2.5-10 \mu \mathrm{m}$ for Bacillus sp. 0.5-1.0 $\mu \mathrm{m}$ by 1.5-5.0 $\mu \mathrm{m}$ for Pseudomonas sp. and $0.5 \mu \mathrm{m}$ by $1.5 \mu \mathrm{m}$ for Staphylococcus sp. [36]. These microorganism sizes are comparable to the diameter of the polyurethane nanofibers.

Furthermore, the porosity of the nanofibers sorbent may increase due to fibers entanglement during the melt blown process therefore creating smaller inter fibers voids. This subsequently, enable the polyurethane nanofiber to trap the microorganism leading to a reduced BOD. For microorganism pore size of $0.22-0.45 \mu \mathrm{m}$ are usually used [37]. For this research, porosity study should be further explored.

Tan et al. [32] had used microbubbles to reduce BOD to $26 \%$ in 60 minutes contact time. Igwe et al. [38] found that boiler fly ash with particle size of 425 $\mu \mathrm{m}$ able to reduce BOD, however, did not further elaborate in detail on their BOD finding.

Table 4 and Figure 7 show that the highest DO percent value was sample with 10 minutes of sorption time and the lowest was sample with no sorption process.

Table 4 Value of dissolved oxygen (DO) of the sample at various contact times

\begin{tabular}{cc}
\hline Sample (sorption time in minutes) & DO \% \\
\hline 0 & 57 \\
2 & 60 \\
6 & 80 \\
10 & 89 \\
\hline
\end{tabular}

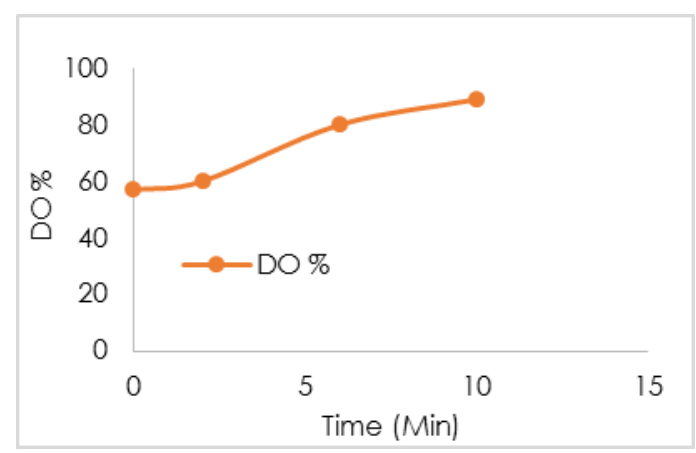

Figure 7 Value of dissolved oxygen (DO) of the sample at various contact times

The increasing level of dissolved oxygen (DO) indicates that the amount of oxygen available in the sample was being consumed by the bacteria or microorganism which affecting the survival of aquatic life such as fish and other aquatic organism. These data are corresponding with the BOD values discussed in the previous paragraph. 


\subsection{CONCLUSION}

In this research, sorption of oil and reducing of $B O D$ from POME were studied with PU nano fiber. The average diameter the fiber was found to be $3.0 \times 10^{3}$ $\mathrm{nm}$. This diameter can lead to a sorbent that has a high porosity leading to a high sorption capacity. However the porosity study should be further studied. The results from the sorption capacity indicated that the highest oil sorption were at 29.28 and $31.40 \mathrm{~g}$ for POME-1 and POME-2 respectively. The oil extraction result shows that $\mathrm{POME}-2$ has the highest oil, removal of $48.31 \%$ at 10 minutes contact time. The BOD values had also reduced to $10 \mathrm{mg} / \mathrm{l}$ after 10 minutes of contact time. Further study on porosity of the nanofiber is needed to find the relationship between porosity and microorganism entrapment. Finally, the findings of this study would give some guidelines for future planning in using nanofibers in the sorption process for removing oil and improvement of BOD in palm oil industry.

\section{Acknowledgement}

This research is supported by SDK0070-2018. The authors fully acknowledged Universiti Malaysia Sabah for the approved fund, which makes this important research viable and effective.

\section{References}

[1] Wu, T. Y., A. W. Mohammad, J. M. Jahim and N. Anuar. 2010. Pollution Control Technologies for the Treatment of Palm Oil Mill Effluent (POME) through End-of-Pipe Processes. Journal of Environmental Management. 91 (7): 1467-1490.

[2] Wu, T. Y., A. W. Mohammad, J. Md. Jahim and N. Anuar. 2007. Palm Oil Mill Effluent (POME) Treatment and Bioresources Recovery Using Ultrafiltration Membrane: Effect of Pressure on Membrane Fouling. Biochemical Engineering Journal. 35(3): 309-317.

[3] Ngarmkam, W., C. Sirisathitkul and C. Phalakornkule. 2011. Magnetic Composite Prepared from Palm Shell-based Carbon and Application for Recovery of Residual Oil From POME1. Journal of Environmental Management. 92(3): 472-479.

[4] Bala, J. D., J. Lalung and N. Ismail. 2015. Studies on the Reduction of Organic Load from Palm Oil Mill Effluent (POME) by Bacterial Strains. International Journal of Recycling of Organic Waste in Agriculture. 4(1): 1-10.

[5] Kamarudin, K. F., D. G. Tao, Z. Yaakob, M. S. Takriff, M. S. A. Rahaman and J. Salihon. 2015. A Review on Wastewater Treatment and Microalgal By-Product Production with a Prospect of Palm Oil Mill Effluent (POME) Utilization for Algae. Der Pharma Chemica. 7(7): 73-89.

[6] Cheng, C. K., M. R. Deraman, K. H. Ng and M. R. Khan. 2016. Preparation of Titania Doped Argentum Photocatalyst and Its Photoactivity Towards Palm Oil Mill Effluent Degradation. Journal of Cleaner Production. 112: $1128-1135$.

[7] Ng, K. H. and C. K. Cheng. 2015. A Novel Photomineralization of POME Over UV-Responsive $\mathrm{TiO}_{2}$ Photocatalyst: Kinetics of POME Degradation and Gaseous Product Formations. RSC Advances. 5(65): 5310053110.
[8] Wahi, R., L. Chuah Abdullah, M. Nourouzi Mobarekeh, Z. Ngaini and T. Choong Shean Yaw. 2017. Utilization of Esterified Sago Bark Fibre Waste for Removal of Oil from Palm Oil Mill Effluent. Journal of Environmental Chemical Engineering. 5(1): 170-177.

[9] Kaman, S. P. D., I. A. W. Tan and L. L. P. Lim. 2016. Palm Oil Mill Effluent Treatment Using Coconut Shell-Based Activated Carbon: Adsorption Equilibrium and Isotherm. MATEC Web of Conferences. 87: 03009.

[10] Chairunnisak, A., B. Arifin, H. Sofyan, M. R. Lubis and Darmadi. 2018. Comparative Study on the Removal of COD from POME by Electrocoagulation and ElectroFenton Methods: Process Optimization. IOP Conference Series: Materials Science and Engineering. 334(1): 012026.

[11] Chew, C. M., M. K. Aroua, M. A. Hussain and W. M. Z. W. Ismail. 2016. Evaluation of Ultrafiltration and Conventiona Water Treatment Systems for Sustainable Development: An Industrial Scale Case Study. Journal of Cleaner Production. 112: 3152-3163.

[12] Tchobanoglous, G., F. L. (Franklin L. Burton, H. D. Stensel and Metcalf \& Eddy. 2003. Wastewater Engineering: Treatment and Reuse. McGraw-Hill.

[13] Lee, Z. S., S. Y. Chin, J. W. Lim, T. Witoon and C. K. Cheng. 2019. Treatment Technologies of Palm Oil Mill Effluent (POME) and Olive Mill Wastewater (OMW): A Brief Review. Environmental Technology \& Innovation. 15: 100377.

[14] Fujihira, T., S. Seo, T. Yamaguchi, M. Hatamoto and D. Tanikawa. 2018. High-rate Anaerobic Treatment System for Solid/Lipid-Rich Wastewater Using Anaerobic Baffled Reactor with Scum Recovery. Bioresource Technology. 263: 145-152.

[15] K. K. Chin; S. W. Lee; H. Mohammad. 1996. A Study of Palm Oil Mill Effluent Treatment Using a Pond System. Water Science Technology. 34(11): 119-123.

[16] Lee, M. W., S. An, S. S. Latthe, C. Lee, S. Hong and S. S. Yoon. 2013. Electrospun Polystyrene Nanofiber Membrane with Superhydrophobicity and Superoleophilicity for Selective Separation of Water and Low Viscous Oil. ACS Applied Materials and Interfaces. 5(21): 10597-10604.

[17] Zhu, H., S. Qiu, W. Jiang, D. Wu and C. Zhang. 2011. Evaluation of Electrospun Polyvinyl Chloride/Polystyrene Fibers as Sorbent Materials for Oil Spill Cleanup. Environmental Science \& Technology. 45(10): 4527-31.

[18] Lin, J., F. Tian, Y. Shang, F. Wang, B. Ding, J. Yu and Z. Guo. 2013. Co-Axial Electrospun Polystyrene/Polyurethane Fibres for Oil Collection from Water Surface. Nanoscale. 5(7): 2745-55

[19] Lin, J., B. Ding, J. Yang, J. Yu and G. Sun. 2012. Subtle Regulation of the Micro- and Nanostructures of Electrospun Polystyrene Fibers and Their Application in Oil Absorption. Nanoscale. 4(1): 176-82.

[20] Lin, J., Y. Shang, B. Ding, J. Yang, J. Yu and S. S. Al-Deyab. 2012. Nanoporous Polystyrene Fibers for Oil Spill Cleanup. Marine Pollution Bulletin. 64(2): 347-52.

[21] Obaid, M., N. A. M. Barakat, O. A. Fadali, M. Motlak, A. A. Almajid and K. A. Khalil. 2015. Effective and Reusable Oil/Water Separation Membranes Based on Modified Polysulfone Electrospun Nanofiber Mats. Chemical Engineering Journal. 259: 449-456.

[22] Sarbatly, R., D. Krishnaiah and Z. Kamin. 2016. A Review of Polymer Nanofibres by Electrospinning and Their Application in Oil-water Separation for Cleaning Up Marine Oil Spills. Marine Pollution Bulletin. 106(1-2): 8-16.

[23] Srinivasan, A. and T. Viraraghavan. 2010. Oil Removal from Water Using Biomaterials. Bioresource Technology. 101 (17): 6594-6600.

[24] Adebajo, M. O., R. L. Frost, J. T. Kloprogge, O. Carmody and S. Kokot. 2003. Porous Materials for Oil Spill Cleanup: A Review of Synthesis. Journal of Porous Materials. (10): 159-170.

[25] Zhu, H., S. Qiu, W. Jiang, D. Wu and C. Zhang. 2011. Evaluation of Electrospun Polyvinyl Chloride/Polystyrene Fibers as Sorbent Materials for Oil Spill Cleanup. Environmental Science \& Technology. 45(10): 4527-31. 
[26] Wu, J., N. Wang, L. Wang, H. Dong, Y. Zhao and L. Jiang. 2012. Electrospun Porous Structure Fibrous Film with High Oil Adsorption Capacity. ACS Applied Materials \& Interfaces. 4(6): 3207-12.

[27] Lee, M. W., S. An, S. S. Latthe, C. Lee, S. Hong and S. S. Yoon. 2013. Electrospun Polystyrene Nanofiber Membrane with Superhydrophobicity and Superoleophilicity for Selective Separation of Water and Low Viscous Oil. ACS Applied Materials \& Interfaces. 5(21): 10597-604.

[28] Lin, J., F. Tian, Y. Shang, F. Wang, B. Ding, J. Yu and Z. Guo. 2013. Co-Axial Electrospun Polystyrene/Polyurethane Fibres for Oil Collection from Water Surface. Nanoscale. 5(7): 2745-55.

[29] Ellison, C. J., A. Phatak, D. W. Giles, C. W. Macosko and F. S. Bates. 2007. Melt Blown Nanofibers: Fiber Diameter Distributions and Onset of Fiber Breakup. Polymer. 48(11): 3306-3316.

[30] Tan, D. H., C. J. Ellison, F. S. Bates and C. W. Macosko, 2008. Impact of Rheology on Meltblown Polymer Nanofibers. AIP Conference Proceedings. 1027(2008): 7274.

[31] Ward, G. 2001. Meltblown Nanofibres for Nonwoven Filtration Applications 1. Filtration and Separation. 38(9): 4243.

[32] Han, W., G. S. Bhat and X. Wang. 2016. Investigation of Nanofiber Breakup in the Melt-Blowing Process. Industrial and Engineering Chemistry Research. 55(1 1): 3150-3156.

[33] Kamin, Z., R. Sarbatly, D. Krishnaiah, A. Tanioka and M. Takahashi. 2019. Melt Blowing Process Conditions for Nanofibers of Polymers for Oil-water Separation in Marine Oil Spills Clean-up Applications: A Short Review. Journal of Mechanical Engineering Research and Developments (JMERD). 42(5): 205-210.

[34] Ahmad, A. L., S. Sumathi and B. H. Hameed. 2005. Adsorption of Residue Oil from Palm Oil Mill Effluent Using Powder and Flake Chitosan: Equilibrium and Kinetic Studies 1. Water Research. 39(12): 2483-2494.

[35] Soleimaninanadegani, M. and S. Manshad. 2014. Enhancement of Biodegradation of Palm Oil Mill Effluents by Local Isolated Microorganisms. International Scholarly Research Notices. 2014: 1-8.

[36] Hardy Diagnostics, http://hardydiagnostics.com/.

[37] Hasegawa, H., K. Naganuma, Y. Nakagawa and T. Matsuyama. 2003. Membrane Filter (Pore Size, 0.22-0.45 Micro M; Thickness, 150 Micro M) Passing-Through Activity of Pseudomonas Aeruginosa and Other Bacterial Species with Indigenous Infiltration Ability. FEMS Microbiology Letters. 223(1): 41-46.

[38] Igwe, J. C., C. O. Onyegbado and A. A. Abia. 2010. Adsorption Isotherm Studies of BOD, TSS and Colour Reduction from Palm Oil Mill Effluent (POME) Using Boiler Fly Ash. Ecletica Quimica. 35(3): 195-208. 